DOROTA ŻUREK

UNIWERSYTET PEDAGOGICZNY W KRAKOWIE

\title{
MIKOŁAJ Z CHRZANOWA. NOWE USTALENIA W SPRAWIE LOSÓW ORGANISTY I KOMPOZYTORA
}

$\bigwedge_{\text {i kompozytorów epoki renesansu, a wzmianki na jego temat pojawiają się }}^{\text {ikołano }}$ niemal we wszystkich wydawnictwach dotyczących historii muzyki ${ }^{1}$. Jak do tej pory ukazał się jeden artykuł w całości jemu poświęcony autorstwa Adolfa Chybińskiego². Badacz ten ustalił, skąd się wywodził Mikołaj z Chrzanowa, kiedy podjął studia i rozpoczął pracę jako organista w katedrze na Wawelu. Odnalazł również szereg wpisów w księgach krakowskiej kapituły katedralnej świadczących o ciężkiej sytuacji materialnej kompozytora. Kolejnym autorem, który wniósł nowe ustalenia do życiorysu Mikołaja z Chrzanowa, był Bolesław Przybyszewski. W publikacji Wypisy źródtowe do dziejów Wawelu zamieścił kilka nowych wzmianek źródłowych dotyczących organisty. Przy tej okazji podał, że posiadał on dział kopalni ołowiu we wsi Pogorzyce, z której - jak przypuszczał - wywodziła się rodzina organisty. Ustalił również, że jego żona miała na imię Regina oraz że był właścicielem domu na

I Informacje o Mikołaju znaleźć można w wydawnictwach słownikowych i podręcznikowych, por. Adolf Chybiński, „Mikołaj z Chrzanowa”, w: Stownik muzyków dawnej Polski do roku I80o, Kraków I949, s. I6; Jerzy Morawski, „Mikołaj z Chrzanowa”, w: Stownik muzyków polskich, red. Józef M. Chomiński, t. I, Kraków I964, s. 85; „Mikołaj z Chrzanowa”, w: Polski Stownik Biograficzny, t. 2I, Wrocław-Gdańsk I976, s. I09; Dzieje muzyki polskiej, red. Tadeusz Ochlewski, Warszawa 1984, s. 37; Katarzyna Morawska, „Mikołaj z Chrzanowa”, w: Renesans, Warszawa 2002 (= Historia muzyki polskiej 2), s. I70. Poświęcono mu także hasła na portalach internetowych: Culture.pl, http://culture.pl/pl/tworca/mikolaj-z-chrzanowa, Wikipedia, https://pl.wikipedia.org/wiki/Miko\%C5\%82aj_z_Chrzanowa, dostęp 7 XII 2017.

2 Adolf Chybiński, „Mikołaj z Chrzanowa”, Przeglad Muzyczny I (I925) nr 20, s. I-5, nr 2I, s. I-5. Ponadto informacje o Mikołaju, w tym wypisy ze źródeł zamieścili Bolesław Przybyszewski, zob.: Wypisy źródtowe do dziejów Wawelu: z archiwaliów kapitulnych i kurialnych krakowskich I5I6-I525, Kraków I970, nr I56, I95 (dalej Wypisy źródtowe I5I6-I525) oraz Wypisy źródtowe do dziejów Wawelu: z archiwaliów kapitulnych i kurialnych krakowskich I536-I538, Kraków 1989, s. XXI, 65, przyp. I (dalej Wypisy źródtowe I536-I538); zob. też: Wacław Urban, „Notatki źródłowe o muzykach polskich w XVI w.”, Muzyka 32 (I987) nr I, s. 59-6I. 
Kazimierzu przy Psim Rynku, który sprzedał w 1532 roku. Przybyszewski zwrócił też uwagę na częste wypłaty przez kapitułę zasiłków dla organisty³.

W czasie kiedy Chybiński badał losy Mikołaja, zaginiona była księga kapituły obejmująca wpisy z 1. I552-86, a ostatnią wzmiankę o organiście autor odnalazł w księgach rachunkowych pod rokiem I555. Wiele lat później wspomniana księga odnalazła się i na jej podstawie Wacław Urban opublikował nowe zapiski źródłowe dotyczące muzyka, ustalając, że zmarł on w I562 r. ${ }^{4}$. Przy tej okazji zasygnalizował kilka problemów dotyczących identyfikacji Mikołaja, organisty krakowskiego. Zauważył bowiem, że w I. poł. XVI w. w źródłach występują dwaj organiści katedralni - Mikołaj z Chrzanowa oraz Mikołaj Bętkowski. Wacław Urban uznał, że albo osoby te są tożsame i w takim przypadku ojciec organisty, mieszczanin chrzanowski wywodził się $\mathrm{z}$ podkrakowskich Będkowic, albo mamy do czynienia z dwoma różnymi osobami o tym samym imieniu. Autor pozostawił te wątpliwości bez odpowiedzi, wskazując jednak na pośrednią przesłankę przemawiającą za identycznością tych osób. Chodziło o wzmiankowaną w źródłach Reginę, żonę Bętkowskiego, a skądinąd wiadomo, że Mikołaj z Chrzanowa był żonaty. Autor wskazał na konieczność przeprowadzenia dalszych kwerend źródłowych, w tym w księgach miejskich Chrzanowa, sądząc, że Mikołaj organista jest tożsamy ze wzmiankowanym w tych źródłach żupnikiem ołowiu Mikołajem Gondkiem (Gendkiem)'s.

Wprawdzie literatura dotycząca losów Mikołaja z Chrzanowa nie jest obfita, niemniej w porównaniu do innych muzyków z tego okresu, cieszył się on sporym zainteresowaniem badaczy. Niektóre dotychczas zebrane informacje wymagają jednak uporządkowania i rozstrzygnięcia - począwszy od kwestii pochodzenia kompozytora, poprzez jego życie rodzinne, po wspomniany problem identyfikacji Mikołaja z Chrzanowa z Mikołajem Bętkowskim. Wszystko to skłoniło mnie do ponownego przyjrzenia się biografii kompozytora, zaś przeprowadzona kwerenda zaowocowała odnalezieniem nieznanych zapisek źródłowych, które rzucają nowe światło na losy organisty i kompozytora oraz pozwalają w pewnym stopniu rozstrzygnąć wspomniane wyżej kwestie.

Dotychczasowi badacze opierali się na wzmiankach źródłowych pochodzących w głównej mierze ze zbiorów Archiwum Krakowskiej Kapituły Katedralnej. Znakomita większość wpisów dotyczy spraw majątkowych Mikołaja i ukazuje jego kłopoty finansowe. Wyłania się $\mathrm{z}$ nich obraz $\mathrm{z}$ jednej strony wybitnego muzyka, cieszącego się uznaniem w środowisku, z drugiej zaś człowieka ciagle walczącego z przeciwnościami losu, nieustannie borykającego się z brakiem środków finansowych. Ponowna kwerenda w tych zbiorach, zwłaszcza w rachunkach kapituły, a także w zasobach Archiwum Kurii Metropolitalnej w Krakowie oraz księgach

3 Wypisy źródtowe I5I6-I525, nr I56, przyp. I, nr 195, Wypisy źródtowe I536-I538, s. XXI, 65.

4 W. Urban, op. cit., s. 60.

5 Ibid., s. 59. Podobnie identyfikuje go K. Morawska, op. cit., s. I70. 
miejskich Krakowa pozwoliła na uzupełnienie naszej wiedzy o życiu Mikołaja. Dalsze informacje przynoszą księgi miejskie Chrzanowa, w których - w gąszczu różnorodnych wpisów - pojawiają się wzmianki o niejakim Mikołaju Gądku i jego rodzinie. Problem pochodzenia organisty, jak wspomniano, był już sygnalizowany przez Urbana i Przybyszewskiego, jednak dopiero sięgnięcie do tych źródeł pozwala na rozstrzygnięcie wątpliwych dotąd kwestii.

Przy analizie zapisków z ksiąg chrzanowskich pojawia się pytanie, czy dotyczą Mikołaja Gądka ojca czy może najsłynniejszego przedstawiciela tej rodziny - jego syna Mikołaja. Wacław Urban sądził, że mamy do czynienia z jedną osobą, jednak nie znał on dokładnie treści ksiąg chrzanowskich. Na podstawie tych wpisów udało się ustalić, że w I484 r. do prawa miejskiego w tym mieście został przyjęty ojciec organisty, Mikołaj Gądek piszący się „de Sobychovczo”. Był on synem szlachcica Stanisława z miejscowości o podobnie brzmiącej nazwie „Sobylniczczye”. Nieprawidłowe wobec tego są przypuszczenia Urbana, jakoby Mikołaj ojciec pochodził z rodziny chłopskiej, ewentualnie drobnoszlacheckiej z podkrakowskiej wsi Będkowice ${ }^{7}$. Mylił się także Przybyszewski, który wysunął tezę, że rodzina kompozytora wywodziła się ze wsi Pogorzyce, leżącej $5 \mathrm{~km}$ na południe od Chrzanowa, swe przypuszczenia opierając na tym, że Gądkowie mieli udziały w kopalni ołowiu w tej miejscowości ${ }^{8}$. Identyfikacja obu miejscowości, z których wywodzili się Gądkowie (ojciec i dziadek kompozytora) przysparza trudności. Jak wspomniano, ojciec pochodził ze wsi „Sobychovczo”. Jedyna miejscowość, której nazwa przypomina wspomnianą w dokumencie, jest Sobiechowo, dziś nosząca nazwę Radziszewo-Sobiechowo, leżąca w województwie podlaskim w gminie Ciechanowiec ${ }^{9}$. Nie mamy żadnych informacji na temat jej średniowiecznych właścicieli, zatem nie można ustalić, czy mogła ona należeć do ojca kompozytora. W przypadku Stanisława, dziadka organisty, najprawdopodobniej chodzi o wieś Skowieszyn, w odniesieniu do której w końcu XV w. zamiennie używano dwóch nazw: „Sobyelzycze alias Skowyesszyn”. W źródłach piętnastowiecznych występuje ona także pod nazwą „Sobielżyce”, „Sobyelzycze”. Wieś ta położona jest $9 \mathrm{~km}$ na północny-wschód od Kazimierza Dolnego. To jedyna miejscowość, której nazwa jest zbliżona do tej, którą zanotowano w zapisce o przyjęciu do prawa miejskiego. Jedynym potwierdzonym źródłowo właścicielem tej wsi o imieniu Stanisław był występujący w l. I46I-70 Stanisław Świemir (Świemirowicz), najpewniej syn odnotowanego w roku I445 Mikołaja Świemira. Niestety o dzieciach Stanisława

6 „Coram nobis [...] veniens Nicolaus Gadek de Sobychovczo nobili domini Stanislai de Sobylniczczye filius suscepit ius civile", Archiwum Narodowe w Krakowie, Akta miasta Chrzanowa, sygn. 7, s. Io6 (dalej ANKr, sygn. 7, dawna sygn. Dep. 36).

7 Teza ta ma związek z uznaniem za tożsamych organistów katedry wawelskiej Mikołaja Gądka i odnotowanego z takim samym tytułem Mikołaja Bętkowskiego, W. Urban, op. cit., s. 59. Podobnie identyfikuje go K. Morawska, op. cit., s. I70.

8 Wypisy źródtowe I536-I538, op. cit., s. XXI, 65. O kwestii tej będzie mowa w dalszej części artykułu.

9 Stownik geograficzny Królestwa Polskiego i innych krajów stowiańskich, t. 9, Warszawa I888, s. 473. 
nic nie wiadomo, nie sposób wobec tego ostatecznie stwierdzić, czy Mikołaj Gądek był synem Stanisława Świemirowicza ${ }^{\mathrm{IO}}$.

Przyjmując, że dziadek Mikołaja pochodził ze Skowieszyna, można zauważyć, że rodzina kompozytora wywodziła się z dość odległych stron i nie ma pewności co skłoniło ojca Gądka do przeniesienia się do odległego miasteczka jakim był Chrzanów. Możliwe, że decyzja ta wiązała się z chęcią podjęcia działalności związanej z handlem ołowiem. Chrzanów był wówczas znanym ośrodkiem handlu tym kruszcem, który wydobywano w okolicznych kopalniach. W zapisce przyjęcia do prawa miejskiego nie wspomina się nic o żonie Mikołaja, choć często - jeśli przyjmowano małżeństwo zaznaczano ten fakt. Wobec tego można przypuszczać, że wówczas był jeszcze stanu wolnego. W zapiskach znajdujących się w księgach chrzanowskich ojca kompozytora nie tytułowano szlachcicem, ale używano określenia „providus”, które było właściwe dla mieszczanina.

Cztery lata po przybyciu do miasta, w I488 r., Mikołaj nabył dom, który znajdował się naprzeciw plebanii, przy ulicy za północnym blokiem rynkowym ${ }^{\mathrm{II}}$. Domostwo to miało pozostać przez długie lata w rękach Gądków. W tym samym roku kupił także inne, bliżej nieokreślone nieruchomości. W I496 r. powiększył swój majątek przez zakup $1 / 4$ łanu roli. Taka wielkość gruntów rolnych wystarczała na wyżywienie jednej rodziny. Księgi miejskie nie dostarczają jednak informacji, jak liczna była rodzina Gądków. W I509 r. Gądek awansował w hierarchii społecznej, kupując dom leżący w rynku w pierzei południowej. W źródłach brak transakcji sprzedaży starego domostwa, co świadczy o tym, że Mikołaj pozostawił sobie ów stary dom leżący naprzeciw plebani. Potwierdzenie tego znajdujemy wiele lat później ${ }^{\mathrm{I2}}$. Ten szybki awans majątkowy ojca organisty wiązał się z pewnością z zaangażowaniem się przez niego w wydobycie ołowiu. Mikołaj był właścicielem części kopalni tego kruszcu, nie wiadomo jednak, kiedy wszedł w jej posiadanie ${ }^{\mathrm{I3}}$. W samym Chrzanowie liczna była grupa osób, które na tej działalności zbudowały rodzinne majątki. Opierając się na zapisach z chrzanowskich ksiąg miejskich, można ustalić, że ojciec - żupnik - zajmował się handlem ołowiem, utrzymując kontakty handlowe z mieszczanami krakowskimi. Z tym przedsięwzięciem związana była także jego działalność kredytowa. Z jednej strony pożyczał pieniądze, z drugiej zaś sam zaciągał kredyty, które inwestował w wydobycie ołowiu. Pełnił także funkcję ławnika i rajcy miejskiego. Zaliczyć go zatem należy do elity tego miasta ${ }^{\mathrm{I}}$. Z zapiski sądowej dokonanej w trzecią niedzielę po Wielkiej Nocy I553 r., wynika, że żupnik Mikołaj

Io „Skowieszyn”, w: Stownik historyczno-geograficzny województwa lubelskiego w średniowieczu, opr. Stanisław Kuraś, Warszawa 1983, s. 213.

II ANKr, sygn. I2, s. 329 („magistri novi fraternitatis resignavit domum iacentem inter Martinum Gawyn parte ex una et inter Mathiam Kysel parte ex altera [...] Nicolao Gandek").

I2 ANKr, sygn. I2, s. I34, 332, 408, 505.

I3 Wypisy I5I6-I525, nr I56, 195 .

I4 ANKr, sygn. I2, s. 46, 54, 65, 68, 78, 8I-82, 88, I08, IIO, II5. 
Gądek zmarł ${ }^{15}$. W drugą niedzielę po Wielkiej Nocy był chory, zatem zgon musiał nastąpić w ciągu tygodnia. Pozostała wdowa imieniem Małgorzata wraz z dziećmi ${ }^{16}$. W źródłach nie znajdujemy zapisu podziału dóbr po zmarłym, ale mogło to wynikać z faktu, że Mikołaj pozostawił zadłużony majątek. W Chrzanowie w kolejnych latach oprócz wdowy Małgorzaty Gądkowej pojawił się ślusarz Józef Gądkowicz ${ }^{17}$. W latach 1578-89 w źródłach odnotowano jeszcze Joachima Gądka, ławnika, który był organistą ${ }^{18}$. Niestety nie ma żadnych danych pozwalających na ustalenie jego powiązań rodzinnych. Wobec tego otwarte musi pozostać pytanie, czy wywodził się z rodziny słynnego organisty, a będąc może jego przyrodnim bratem, kultywował rodzinną tradycję?

Szczegółowa analiza powyższych przekazów źródłowych i porównanie ich z tymi, które dotyczą organisty, pozwala na wysunięcie stwierdzenia, że ojciec kompozytora żył do I553 r. i niemal wszystkie zapiski w księgach chrzanowskich dotyczą jego osoby. Wedle tych ustaleń Małgorzata Gądkowa na pewno nie była matką organisty, a raczej jego macochą, organista miałby też przyrodnie rodzeństwo. Natomiast odrzucić należy tezę, że ojciec zmarł w początkach XVI w. i wszystkie zapiski w księgach miejskich Chrzanowa począwszy od I520 r. dotyczą organisty katedralnego. W takim przypadku nie znajdują wytłumaczenia dwie różne daty jego śmierci. Z tym założeniem stoją w sprzeczności także imiona rzekomych żon organisty - Jadwigi i Reginy, o czym szczegółowo niżej. Na rzecz takiej interpretacji przemawia również bardzo ożywiona działalność Mikołaja w Chrzanowie, gdzie był ławnikiem, a następnie rajcą, zajmował się także handlem ołowiem. Wydaje się, że syn - organista katedralny, nie byłby w stanie tak często przebywać w mieście, gdyż sprawowanie urzędów wymagało częstej, jeśli nie stałej obecności. W I. poł. XVI w. mamy do czynienia z dwoma Mikołajami Gądkami, ojcem - żupnikiem i rajcą chrzanowskim oraz jego synem - kompozytorem i organistą.

Mikołaj organista katedralny i kompozytor, syn Mikołaja Gądka mieszczanina chrzanowskiego, kilkakrotnie występuje w źródłach jako Mikołaj Gądkowicz lub Bętkowski. W źródłach krakowskich w aktach oficjała tylko jeden raz, w I52I r., a więc na początku jego kariery, zapisano go jako Mikołaja Ganthkowicza „arcium baccalarium, organistam in arce Cracouiensi"' ${ }^{2}$. W I55I r. w księgach miejskich Chrzanowa określono go mianem Mikołaja Gądka mieszczanina i organisty zamku krakowskiego. Organista zamkowy Mikołaj z nazwiskiem Bętkowski pojawił się w księgach grodzkich krakowskich w I550 r. oraz dwukrotnie w księgach miejskich

I5 Dwóch mieszczan zeznało, że chodzili do nieboszczyka Gądka "gdy na śmiertelnej leżał pościeli”, który zeznał, że nieboszczyk Wojciech Kruk rozkazał synowi Janowi wziąć „wszystko naczynie z góry na beczemskym" (chodzi o kopalnię ołowiu), którą z Gądkiem mieli wspólnie, ANKr, sygn. I3, s. 62.

I6 ANKr, sygn. 6, s. 9 („Małgorzata Gądkowa relicta post maritum suum olim Nicolaum Gądek”).

I7 Był on ławnikiem i rajcą miejskim, a w źródłach wzmiankowany jest w l. I55I-72, w I572 r. już nie żył (ANKr, sygn. I3, s. 8, II, I53, sygn. I4, s. 245).

I8 ANKr, sygn. I4, s. 593, sygn. I5, s. 78, 88, I04.

I9 Archiwum Kurii Metropolitarnej w Krakowie (dalej AKM), A. Off. 44, s. 453. 
krakowskich w I555 r. ${ }^{20}$. Najczęściej jednak pisze się o nim jako o Mikołaju z Chrzanowa lub jedynie określając mianem organisty zamkowego czy katedralny. Tak zapisywano go w źródłach katedralnych i biskupich. Z określeniem „z Chrzanowa” pojawia kilkunastokrotnie, począwszy od zapiski przyjęcia go na studia uniwersyteckie. Przy tym wpisie, podobnie jak i przy promocji nie użyto nazwiska, określając go za pierwszym razem jako „Mikołaj syn Mikołaja z Chrzanowa”, za drugim zaś zapisano tylko „Mikołaj z Chrzanowa”. Najczęściej w źródłach katedralnych występuje jako Mikołaj organista, przy czym we wszystkich wpisach w księgach rachunkowych używano wyłącznie tego określenia. Pisząc o nim ostatni raz, już po śmierci określono go jako „honorati olim Nicolai a Chrzanow, ecclesiae veteran servitoris” ${ }^{21}$.

Nie wiadomo kiedy ani gdzie się urodził. Zakładając, że jego ojciec przybywając do Chrzanowa był stanu wolnego, syn musiał urodzić się już w tym mieście. Jerzy Morawski za datę jego narodzin przyjmuje 1485 r. czyli rok po osiedleniu się ojca w mieście, Wacław Urban z kolei datuje jego narodziny na rok I490; podkreślić jednak należy, że są to jedynie domniemane daty ${ }^{22}$. Mikołaj miał z pewnością przynajmniej kilkanaście lat, kiedy po raz pierwszy został odnotowany w źródłach. Było to w I5O7 r., w którym zapisał się na Uniwersytet Krakowski ${ }^{23}$. Tam też dopiero po sześciu latach, w I5I3 r. uzyskał tytuł bakałarza ${ }^{24}$. Podjęcie studiów wiązało się z dużymi nakładami finansowymi, zapewne jego ojciec był wówczas w dobrej sytuacji materialnej, o czym świadczy wspomniany wcześniej zakup domu w rynku. Pięć lat po uzyskaniu stopnia bakałarza, 5 III I5I8 r., Mikołaj objął stanowisko organisty w katedrze na Wawelu i zamieszkał w domu psałterzystów²5. W I520 r. toczyła się przed sądem biskupim sprawa o kradzież piszczałek do organów przeciwko niemu i Stanisławowi Varpanska, budowniczemu organów ${ }^{26}$. W procesie zeznawała wdowa Anna Varpasczina (może matka Stanisława), twierdząc, że nic złego jej nie wiadomo o obu oskarżonych ${ }^{27}$. Rok później, w I52I r., Mikołaj Gantkowicz, a zatem nasz

20 ANKr, sygn. 5, s. I50. ANKr, Akta miasta Krakowa, sygn. 759, s. 65I. Wacław Urban odnalazł zapiskę z 1550 r., w której własnoręczny podpis w księgach grodzkich złożył „Nicolaus Organista”, którego utożsamia z Bętkowskim, W. Urban, op. cit., s. 59.

2I Archiwum Krakowskiej Kapituły Katedralnej (dalej AKK), Acta Actorum Capitularia Ecclesiae Cracoviensis (dalej Aa) 5 , k. 457.

22 J. Morawski, „Mikołaj z Chrzanowa”, op. cit.; tę datę przyjęto w literaturze, zob.: W. Urban, op. cit., s. 6I. W obu przypadkach brak źródeł informacji, które nigdzie nie znajdują potwierdzenia.

23 „Nicolaus Nicolai de Chrzanow” przy wpisie uiścił opłatę w wysokości 4 groszy, zob.: Metryka Uniwersytetu Krakowskiego z lat I400-I508. Biblioteka Jagiellońska rkp. 258, wyd. Antoni Gąsiorowski, Tomasz Jurek, Izabela Skierska, przy współpracy Ryszarda Grzesika, t. I, Kraków 2004, s. 636. Jeśli przyjąć, że urodził się w 1485 r., studia uniwersyteckie rozpocząłby dopiero w wieku 22 lat.

24 Statuta nec non liber Promotionum Philosophorum ordinis in Universitate Studiorum Jagellonica (I402-I849), wyd. Józef Muczkowski, Kraków I849, s. I57.

25 AKK, sygn. Aa 2, k. 32Iv.

26 Stanisław prowadził prace nad budową organów w katedrze krakowskiej, po ich zakończeniu nadal świadczył swe usługi dla kapituły, A. Chybiński, op. cit., s. 3.

27 Wypisy źródtowe I5I6-I525, op. cit., nr I56, oryg. AKM, sygn. A. Off. 57, s. 79. 
organista, sprzedał za 36 florenów część kopalni w dobrach Gabriela Pogórskiego, która przypadła na niego w ramach ojcowizny ${ }^{28}$.

W związku z otrzymaniem posady $\mathrm{w}$ Krakowie Mikołaj miał możliwość zamieszkania we wspomnianym domu psałterzystów do czasu ożenku. Związek małżeński zawarł najpóźniej w 1526 r., z którego pochodzi zapis o udzieleniu mu przez kapitułę pieniężnej rekompensaty ze względu na utratę prawa mieszkania w tym domu. Zapewne w tym czasie nabył dla swojej rodziny nieruchomość w podkrakowskim Kazimierzu. Był to drewniany dom z ogrodem leżący przy Psim Rynku, czyli placu w pobliżu cmentarza nieistniejącego dziś kościoła św. Wawrzyńca w południowo-wschodnim narożniku Kazimierza. Dom ten spłonął w I530 r. ${ }^{29}$. W związku z tym nieszczęśliwym wypadkiem kapituła dwukrotnie wspomagała finansowo Mikołaja, przeznaczając pewne sumy na odbudowę pokrycia dachowego w zniszczonej nieruchomości ${ }^{30} .7$ VI I532 r. kapituła przekazała mu io florenów na budowę domu ${ }^{31}$. Tymczasem io czerwca tego roku Mikołaj sprzedał wspomniany dom w Kazimierzu Mikołajowi Pieczonce za 40 grzywien, z zastrzeżeniem, że nowy właściciel nie może bez zgody rajców sprzedać go szlachcicowi lub duchownemu ${ }^{32}$. Jak udało mi się ustalić, organista niebawem nabył dom w Krakowie w zaułku św. Piotra przy ul. Grodzkiej, gdzie jako właściciel był wzmiankowany w I535 r., będąc sąsiadem Mikołaja pergaminnika, który wówczas wprowadził się do domu kapituły zwanego Lissagora (Łysa Góra) ${ }^{33}$. Być może owa wspomniana darowizna w kwocie io złotych przeznaczona była na budowę tej właśnie nieruchomości. Mikołaj dostawał regularnie od kapituły ekwiwalent za opłacenie i utrzymanie tego domu, nie płacił także od niego szosu - podatku królewskiego ${ }^{34}$. Pensja z pewnością nie wystarczała organiście

28 AKM, A. Off. 44, s. 453; Wypisy źródtowe I5I6-I525, nr I95 - 6 VII I52I r., Marcin Porębski z Chrzanowa i Jan Trathkop (Tratkop) z Krakowa „emisse unum actuale montis [...] apud honorabilem dominum Nicolaum Ganthkowicz arcium baccalarium, organistam in arce Cracouiensi, qui quidem dominus Nicolaus actuale predictum, sortem suam paternam, vendidisse pro triginta sex florenis monete et numeris polonicalis [...]".

29 Wypisy źródtowe I526-I535, s. I35-136, Stanisław Tomkowicz, Ulice i place Krakowa w ciagu dziejów, Kraków I926, s. 234.

30 AKK, sygn. Aa 3, k. 67; Wypisy źródtowe 1530-I533, nr 479: 23 IX I530 r. kapituła dała 4 floreny „Nicolao organiste pro restauracione domus ipsius, quam allegavit sibi fore detectam propter ignis sedacionem”, AKK, Fabr. Crac. 2, k. 3. W I53I r. w związku z chorobą również dostał wsparcie finansowe od kapituły, Aa3, k. 67v; zob.: A. Chybiński, op. cit., s. 5.

AKK, Fabr. Crac. 2, k. I4.

32 Cracovia artificum I50I-I550, wyd. Jan Ptaśnik, t. 5, zesz. 3, Kraków 1948, nr I333.

33 Ibid., nr 834: I3 IX I535 r. Wolffgangus „,venator regius” sprzedał dom „retro ecclesiam dici Petri in platea Transversali Castriensi” (część dzisiejszej ul. Poselskiej, od ul. Grodzkiej do kościoła św. Józefa) „inter Nicolai organiste castriensis et Joannis Gol aromatarii", Mikołajowi pergaminnikowi za 300 florenów (oryg. ANKr, Scab. Crac. sygn. II, s. 558). W marcu 1545 r. przed sądem biskupim stanęła sprawa donosu na Mikołaja pergaminnika, który budując sobie murowany dom, nie zostawił wolnej przestrzeni na mur międzydziałkowy, jak nakazywał zwyczaj są̧iedzki (Wypisy źródtowe I542-I545, $\mathrm{nr}$ 1752).

34 Przypuszczenie takie można wysunąć, opierając się na spisie podatników z I55I r., gdzie Mikołaj organista jest odnotowany przy ulicy Grodzkiej, ale bez podania kwoty szosu (Cracovia artificum I55I-I560, zesz. I, nr 327). Jeśli nieruchomość ta należała do kościoła, była zwolniona z opłat. 
na utrzymanie rodziny i to zapewne zmusiło Mikołaja do poszukiwania innych możliwości zarobkowania. Co ciekawe, swoją uwagę skierował w stronę działalności handlowej. Być może wynikało to z doświadczeń, jakie wyniósł z domu rodzinnego. W I534 r. wraz z pierwszą żoną Jadwigą otrzymał od władz miasta ekspektatywę na urządzenie kramu ze szkłem ${ }^{35}$. Nie wiadomo, czy ostatecznie otrzymali ów kram. Najpewniej był to ciężki pod względem finansowym okres w życiu Gądka. Przypuszczenia takie można wysnuć, czytając zapiskę z czerwca I 538 roku. Organista skarżył się wówczas przed kapitułą na niskie wynagrodzenie, co było według niego przyczyną różnych niedogodności, jakie musiał znosić. Zaznaczył, że jeśli nie uzyska wyższej pensji, zmuszony będzie szukać innej posady. Kapituła przychyliła się do jego prośby, przyznając mu szereg ulg i umożliwiając grę w katedrze w czasie dodatkowych świąt, co miało zwiększyć jego dochody ${ }^{36}$. Świadczy to o jego wysokiej pozycji i uznaniu, jakim musiał się cieszyć w środowisku katedralnym. Mikołaj kolejny raz jest wzmiankowany w źródłach w I543 r., kiedy toczył w Krakowie proces z Józefem organistą ${ }^{37}$. W lutym tego roku znalazł się w Bieczu, gdzie jako rzeczoznawca wraz z Janem z Pilzna i Stanisławem z Tuchowa dokonał oględzin nowo zbudowanych organów dla tamtejszej fary ${ }^{38}$. II X I546 r. Mikołaj grał na instrumencie muzycznym na dworze królewskim, zaś w kolejnym roku zlecono mu wydanie opinii w sprawie stanu organów w katedrze wawelskiej39. Jak można zauważyć, Mikołaj podejmował się różnych prac i zadań służących poprawie sytuacji finansowej swojej rodziny. W tym okresie musiała umrzeć Jadwiga, bowiem od I544 r. jako jego żona wzmiankowana jest Regina Organiścina, wnuczka Macieja introligatora i - jak ustaliłam - córka szewca Marcina Lipnickiego ${ }^{40}$.

W tym miejscu należy wyjaśnić kwestię imienia żony organisty. Przybyszewski podaje, że była to Regina, a informację tę zaczerpnął z zapiski z I550 r., w której wystąpił Mikołaj organista z żoną o takim imieniu ${ }^{41}$. Tymczasem w źródłach z I534, I 538 i I 539 r. jako jego żona pojawia się Jadwiga ${ }^{42}$. Bezsprzecznie należy więc uznać, że tak właśnie miała na imię pierwsza żona Mikołaja Gądkowicza. Wszystko wskazuje zaś na to, że najpóźniej w I544 r. organista ożenił się ponownie, z kobietą o imieniu

35 Ibid., nr I344; W. Urban, op. cit., s. 6I.

36 AKK, Aa 3, k. 203; A. Chybiński, op. cit., cz. I, s. 5.

37 AKM, A. Off., t. 77, s. 306.

38 Mikołaj organista grodu krakowskiego, Franciszek Bujak, Materiaty do historyi miasta Biecza I36I-I632, Kraków I9I4, nr I92; A. Chybiński, op. cit., cz. I, s. 5.

39 AKK, Aa 4, k. 237; Materyaty do historyi stosunków kulturalnych w XVI w. na dworze królewskim polskim, opr. Stanisław Tomkowicz, Kraków I9I5, s. 9. A. Chybiński (op. cit., cz. 2, s. I-2) przytoczył opinię spisaną przez Mikołaja w języku polskim, która została wpisana do akt.

40 Wypisy źródtowe 1542-1545, op. cit., $\mathrm{nr}$ I625, 1692.

4I W tej zapisce występuje z nazwiskiem Bętkowski. zob.: AKK, sygn. Aa 3, k. I5v. Tutaj nie podano imienia żony Mikołaja. Zob.: Wypisy źródtowe I536-I538, s. 65; W. Urban, op. cit., s. 59.

42 Cracovia artiuficium, nr I344. Wspomniał o niej W. Urban, op. cit., s. 6I. 
Regina $^{43}$. Z nią wiąże się kwestia tożsamości Mikołaja z Chrzanowa i Mikołaja Bętkowskiego. Jak wspomniano, w literaturze pojawiła się propozycja identyfikacji Mikołaja Gądkowicza ze szlachcicem Mikołajem Bętkowskim, wzmiankowanym w źródłach jako organista zamkowy. Propozycję taką wysunął Urban, zakładając, że rodzina Gądkowicza, dokładniej jego ojciec, wywodziła się z podkrakowskiej wsi Będkowice, zaś „Gądek” było przezwiskiem wywodzącym się być może od tamtejszego lasu Kątki. Badacz nie wykluczał innej ewentualności, a mianowicie, że organista przyjął nazwisko żony. Autor sądził, że Mikołaj miał obywatelstwo Kazimierza i Chrzanowa, dodatkowo twierdząc, że nazwisko Bętkowski występuje w Chrzanowie do dziś. To stwierdzenie wymaga sprostowania, bowiem do połowy XVII w. w Chrzanowie nie odnotowano osób o tym nazwisku ${ }^{44}$, wobec czego poszlaka ta nie ma żadnego uzasadnienia. Jak dowiedziono powyżej, odrzucić należy hipotezę o pochodzeniu Mikołaja z Będkowic, co jednak nie zmienia faktu, że tożsamość tych dwóch osób jest niemal pewna. W odniesieniu do Mikołaja Bętkowskiego, w wyniku przeprowadzonych badań udało się ustalić, że po raz pierwszy osoba ta wzmiankowana była w I545 roku. Jego żoną była Regina Lipnicka, córka szewca, mieszczanina krakowskiego Marcina Lipnickiego i Anny, a siostra znanego wówczas w Krakowie doktora medycyny Erazma Lipnickiego ${ }^{45}$. Po śmierci Erazma, która miała miejsce między I553, a I554 r., a następnie jego żony, co nastąpiło II I I555 r., kapituła ogłosiła, że kanonicy mają poprzeć przed radą miasta Krakowa kandydaturę Mikołaja z Chrzanowa na opiekuna jego powinowatych - dzieci Erazma Lipnickiego ${ }^{46}$. Nie wiadomo, dlaczego odrzucono kandydaturę Mikołaja, bowiem opiekę przyznano dwóm mieszczanom krakowskim - Janowi Zimmermannowi młodszemu oraz Michałowi Lencowi ${ }^{47}$. Natomiast z innej wzmianki wynika, że po śmierci Erazma Mikołaj Bętkowski został prawnym opiekunem wdowy Anny jako jej zięć i w związku $\mathrm{z}$ tym reprezentował ją przed sądem ${ }^{48}$. Podsumowując powyższe zapiski, stwierdzić

43 Wypisy źródtowe I542-I545, nr I625; AKM, A. Off. 74, s. 694-695.

44 W. Urban, op. cit., s. 59-6I. Wynika to z przeprowadzonych przeze mnie badań socjotopograficznych nad społeczeństwem miasta, zob.: Dorota Żurek, Przestrzeń i społeczeństwo Chrzanowa średniowiecznego i nowożytnego, Kraków 2015 .

45 W I545 r. w testamencie Marcina Lipnickiego zapisano, że mężem jego córki Reginy jest szlachcic Mikołaj organista zamkowy („nobilus dominus Nicolaus organista in arce cracoviensis”), AKM, A. Off. 74, s. 694-695. W I555 r. wzmiankowany jest Mikołaj Bętkowski organista zamkowy, zięć wdowy Anny Lipnickiej, ANKr, Akta miasta Krakowa, sygn. 759, s. 65I. W I558 r. odnotowano: „honesta domina Regina Lipniczka dominum Nicolai organiste arcis cracoviensis uxor”, AKM, A. Off. 86, s. 986. Te wzmianki pozwalają na utożsamienie Mikołaja organisty z Mikołajem Bętkowskim.

46 AKK, Aa 5, k. I8ıv. Nie jest prawdą, jak podaje Przybyszewski, że Mikołaj objął opiekę nad jego dziećmi (Wypisy źródtowe ${ }_{53} 36-1538$, s. 65). Ponadto Erazm osierocił tylko jedno dziecko, córkę Urszulę.

47 Jan Lachs, Kronika lekarzy krakowskich do końca XVI w. Przyczynki archiwalne, Kraków I909, s. 52-53, Aleksander Birkenmajer, „Czy Hilary z Wiślicy był szermierzem systemu heliocentrycznego w Krakowie?”, Kwartalnik Historii Nauki i Techniki 4 (1959) nr 3, s. 434-436, 446.

48 Anna uczyniła plenipotentem szlachetnego Mikołaja „Benthkowsky generum suum atque organistam castriensem", ANKr, Akta miasta Krakowa, sygn. 759, s. 65I. 
można, że tym co łączy Mikołaja z Chrzanowa z Mikołajem Bętkowskim, jest osoba Erazma Lipnickiego, z którym Mikołaj z Chrzanowa miał być spowinowacony. Takie więzi są potwierdzonew przypadku Bętkowskiego. W związku z tym druga żona Mikołaja o imieniu Regina musi być tożsama z Reginą Lipnicką. Dodatkowo obaj wymieniani są jako organiści zamkowi, a w rachunkach kapituły znajdujemy wypłaty pensji tylko dla jednego organisty. Zastanowienia wymaga kwestia, czy określenie „organista zamkowy” mogło być stosowane zarówno w odniesieniu do organisty katedralnego, czy również działającego na dworze królewskim. Jednak wśród tych ostatnich odnotowanych w pierwszej połowie XVI w. nie spotykamy żadnego o imieniu Mikołaj. Wszystko wskazuje więc na to, że Mikołaj Bętkowski i Mikołaj Gądkowicz z Chrzanowa to ta sama osoba. Pozostaje jednak pytanie, dlaczego Mikołaj z Chrzanowa miałby zmienić nazwisko. Być może wynikało to z faktu, że w tym samym czasie żyła i działała na Wawelu inna osoba nosząca podobne nazwisko. Był to Bartłomiej Gątkowski, wikariusz generalny krakowski, notariusz arcybiskupa, wielokrotnie wzmiankowany w źródłach.

W źródłach chrzanowskich zachowała się tylko jedna wzmianka o naszym kompozytorze, która pochodzi z I55I roku. Na jej podstawie można sądzić, że Mikołaj musiał pojawiać się $\mathrm{w}$ rodzinnym mieście, bowiem jesienią (przed św. Jadwigą, tj. przed I4 października) wspomnianego roku pożyczył ıo złotych tamtejszemu mieszczaninowi Piotrowi Karwowskiemu, który poręczał tę sumę swoim domem w rynku i zobowiązywał się spłacić ją w dwóch ratach. Ta notatka, w której Mikołaja określono mianem mieszczanina i organisty zamku krakowskiego, wskazuje, że z całą pewnością mamy do czynienia z Mikołajem Gądkiem synem ${ }^{49}$. Być może w tym okresie jego sytuacja finansowa nieco się poprawiła. W latach I55I-52 w źródłach katedralnych odnotowano wypłaty kilkuzłotowych sum dla organisty ${ }^{5 \circ}$.

W kolejnych latach kapituła jeszcze kilkukrotnie wspomagała finansowo swojego organistę. W szczególnie trudnej sytuacji był w I555 r., kiedy wraz z żoną skarżył się, że nie mogą wyżywić siebie i dzieci, a biskup odmówił mu zwykłej pensji Io grzywien, przydzielając trzy chleby tygodniowo ${ }^{51}$. Sądzić można, że dzieci były małoletnie, a zatem zrodzone $\mathrm{z}$ drugiego małżeństwa $\mathrm{z}$ Reginą. Potwierdzeniem tego jest odnaleziona przeze mnie zapiska w rachunkach kapituły z I556 roku. Podano w niej, że notariuszowi kapitulnemu wypłacono dwa talary za ochrzczenie dwóch synów Mikołaja organisty ${ }^{52}$. W kolejnym roku odnotowano, że Mikołaj nadal wnosi prośby o wsparcie, ale nie udzielono mu nic ponad wspomniane trzy chleby ${ }^{53}$. Do tej pory

ANKr, sygn. 5, s. I5O-I5I („,dominus Nicolaus Gądek ciuis et organista castri cracoviensis”). Wiele lat wcześniej od września do końca listopada I527 r. w związku z panującą w Krakowie zarazą Mikołaj opuścił miasto (A. Chybiński, op. cit., cz. 2, s. 4). Nie wiadomo, gdzie się udał wraz z rodziną, może przebywał wówczas w Chrzanowie?

so W. Urban, op. cit., s. 60.

5I AKK, Aa 5, k. 196v-197, W. Urban, op. cit., s. 60.

52 AKK, R. Cap. II, k. 89v („notario capituli nostro a dominis ad baptisandos duos filios Nicolao organiste dati sunt talari $2 ")$.

53 AKK, Aa 5, k. 253v. 
sądzono, że zapiska z I557 r. jest ostatnim świadectwem życia Mikołaja ${ }^{54}$. Tymczasem w rachunkach kapituły znajduje się wpis z 28 VI I56I r., w którym kapituła udzieliła organiście wsparcia w kwocie 6 grzywien i I2 groszy na zorganizowanie ślubu jego córkis5. Ta ważna wzmianka pozwala stwierdzić, że Mikołaj oprócz dwóch synów, miał także córkę, najpewniej z pierwszego małżeństwa z Jadwigą, skoro w I56I r. była już dorosła. Ostatni wpis w źródłach dotyczący Mikołaja pochodzi z I 562 roku. Wówczas wspomina się o nim jako o zmarłym, a 24 lipca tego roku stanowisko organisty w kościele katedralnym objął Jakub ${ }^{56}$. Możemy zatem ustalić datę śmierci organisty na okres między 28 VI I56I r. a 24 VII 1562 roku.

Ponowne przeanalizowanie dotychczasowej wiedzy na temat słynnego organisty i kompozytora oraz uzupełnienie tych informacji o nowe źródła zaowocowało uporządkowaniem kolejnych zdarzeń i wyjaśnieniem kilku zagadek z jego życiorysu. Wątpliwości nie powinna już budzić kwestia tożsamości Mikołaja z Chrzanowa z Mikołajem Gądkiem zwanym też Gątkowiczem (Gantkowiczem). Organista był synem Mikołaja Gądka, przyjętego w I484 r. do prawa miejskiego w Chrzanowie, a wnukiem szlachcica Stanisława. Data narodzin przyszłego muzyka nie jest znana, ale niewątpliwie miało to miejsce u schyłku XV wieku. Nie sposób określić, ile miał lat w I507 r. kiedy podjął studia uniwersyteckie ${ }^{57}$. Przy założeniu, że wówczas liczył sobie między is a 20 lat, jego narodziny można datować na lata I487-92. Szkołę parafialną Mikołaj najpewniej ukończył w Chrzanowie. Po opuszczeniu rodzinnego miasta utrzymywał z nim jakieś kontakty, jednak zapewne z uwagi na liczne zajęcia w stolicy nie bywał tam często. Jak miało się niebawem okazać, Mikołaj na stałe związał się z Krakowem, gdzie dalej kształcił się, pracował i założył rodzinę. Poddane analizie wzmianki źródłowe skłaniają do stwierdzenia, że Mikołaj Gądkowicz jest tożsamy z Mikołajem Bętkowskim. Jak ustaliłam z dwóch małżeństw z Jadwigą i z Reginą z Lipnickich doczekał się co najmniej trojga dzieci - córki i dwóch synów. Jego pierwszym mieszkaniem był dom psałterzystów na Wawelu, po opuszczeniu którego zamieszkał w podkrakowskim Kazimierzu. Po około sześciu latach ponownie przeprowadził się i zamieszkał tuż u stóp Wawelu - w okolicy ulicy Grodzkiej, gdzie wzmiankowany był jeszcze w I55I r. czyli prawie dwadzieścia lat po przeprowadzce. To oznacza, że najpewniej tam znalazł docelowy dom dla siebie i rodziny.

54 Autorzy hasła w Polskim Stowniku Biograficznym nie mieli pewności, czy występujący po I555 r. w źródłach kapituły Mikołaj organista jest tożsamy z Mikołajem z Chrzanowa (zob. przyp. I).

55 AKK, R. Cap. I5, k. $89 v$.

56 „post morte olim Nicolai a Chrzanow”, AKK, Aa 5, k. 457; W. Urban, op. cit., s. 60.

57 Nie istniały regulacje określające minimalny wiek osób przyjmowanych na studia uniwersyteckie. Źródła także nie pozwalają na ustalenie średniego wieku, przykładowo Jan Długosz podjął studia mając trzynaście lat, z kolei z końca XV w. pochodzą informacje o kilku studentach Uniwersytetu Krakowskiego, którzy immatrykulowali się w wieku 24, I9 i I8 lat. Szerzej na ten temat zob.: Krzysztof Boroda, Studenci Uniwersytetu Krakowskiego w późnym średniowieczu, Kraków 2010, s. 43-44. 


\section{MIKOŁAJ OF CHRZANÓW. NEW FINDINGS CONCERNING THE BIOGRAPHY OF THE ORGANIST AND COMPOSER}

This article represents an attempt to review the biography of Mikołaj of Chrzanów a famous composer and organist of Cracow Cathedral active in the first half of the sixteenth century. Analysis of previous academic findings revealed gaps and contradictory information. Further preliminary research in the Archives of Cracow Cathedral Chapter and the Metropolitan Curia in Cracow, as well as the Municipal Records of both Cracow and, most importantly, Chrzanów, not previously studied from this perspective, resulted in the discovery of new records concerning Mikołaj and his family. Adding the new findings to the previously available information has made it possible to systematise the current state of knowledge and to offer new insights. It has been established that Mikołaj came from the minor nobility, and not from the peasantry or townsfolk, as was believed. In the late fifteenth century, his father, Mikołaj Gądek, became a burgher of Chrzanów, where he settled permanently. Analysis of the sources has made it possible to retrace the biography of Mikołaj Gądek, mining overseer of Chrzanów and holder of other offices in the town. His son, also Mikołaj, after completing his studies, became organist of Wawel Cathedral in Cracow and remained associated with the cathedral and the city for the rest of his life. He moved home several times: he initially lived in the psalm singers' house on Wawel Hill, then moved to an estate in Kazimierz, near Cracow, before eventually settling on Grodzka Street in Cracow. In all likelihood, the new findings confirm the hypothesis according to which Mikołaj of Chrzanów and Mikołaj Bętkowski were in fact the same person. Also, it has been discovered that the organist was married twice and had at least three children, a daughter and two sons. It is probable that additional preliminary research in the vast municipal archives in Cracow would reveal information about his widow and children. Providing for his family required considerable financial outlay, which forced Mikołaj to continuously seek new sources of income. On several occasions, he complained to the Chapter about his difficult financial situation. Held in great esteem by the Cathedral milieu, he died in 1563 .

Translated by Pawet Gruchata

Dr Dorota Żurek, adiunkt w katedrze Historii średniowiecznej w Instytucie Historii i Archiwistyki Uniwersytetu Pedagogicznego w Krakowie. Zajmuje się dziejami miast (zwłaszcza małopolskich) i mieszczaństwa w późnym średniowieczu. Autorka książki Przestrzeń i społeczeństwo Chrzanowa późnośredniowiecznego i nowożytnego (Kraków 2015), za którą zdobyła I nagrodę Fundacji Naukowej im. A. Gieysztora.

dorota.zurek@up.krakow.pl 